\title{
A Monograph on: Educational Linguistics, its Origin, Definitions and Issues it Accounts for
}

\author{
Ahmed Mohammed Saleh Alduais, ${ }^{1, *}$ \\ ${ }^{1}$ Department of English Language, King Saud University KSU, Riyadh, Kingdom of Saudi \\ Arabia KSA \\ *Correspondence: Department of English Language, King Saud University KSU, Riyadh, \\ Kingdom of Saudi Arabia KSA
}

Tel: 966-551-367-208Ｅ-mail: ibnalduais@yahoo.com

Received: September 22, 2012 Accepted: November 4, 2012 Published: December 16, 2012

doi:10.5296/ije.v4i4.2437～URL: http://dx.doi.org/10.5296/ije.v4i4.2437

\begin{abstract}
Purpose: To present argumentatively Spolsky's proposed idea of exempting the field of applied linguistics from his proposed field educational linguistics and Hult's view that only the history of educational linguistics can be inextricably linked to applied linguistics.

Method: Accounting for the history of educational linguistics in terms of its origin, definitions, and issues it accounts for. Besides, the author presents his own proposed models for the field of educational linguistics to be discussed against those models proposed by Spolsky (the father of educational linguistics).

Results and conclusions: Whether applied linguistics and educational linguistics are the same remains a controversial issue, but it is very clear that applied linguistics could include educational linguistics but not vice versa.
\end{abstract}

Keywords: educational linguistics; applied linguistics; fields of linguistics 


\section{Introduction}

Principally, language learning at least as native is [as old as human beings]. However, the need of transferring the knowledge of one advanced nation to another developing nation requires the educated people of the developing nation to learn the language of that developed nation. By the time, the importance of learning another language rather than one's native language becomes not only for knowledge transfer, but for a number of educational, academic, social, economic, financial, tour, and etc. purposes. Thus, the field of language learning, teaching and pedagogy has been increasingly and considerably developed during the recent centuries starting gradually from the age of Renaissance.

Strictly speaking and theoretically, the study of language is very old but later on one century after another, at least one or two new fields are added to enhance and extend the study of language in all over the world. Simply put, the study of language has been considerably developed to the extent some linguists have started to seriously but arguably consider it as a [science] rather than a branch of (Humanities). This considerable development in the field of language (linguistics) has led to the evolution of other branches to prove it as a science rather than just only merely predicted theories. Namely, this new evolved field is called as (Applied Linguistics).

As a matter of fact, applied linguistics has started in nearly the 1940s as a term referring to [second] and foreign language pedagogy, but I personally believe that the real implication for this term is the applied side for all matters of language, those which account for issues such educational linguistics, clinical linguistics [psycholinguistics and neurolinguistics], forensic linguistics, sociolinguistics, and so on and so forth.

This research-paper accounts for the issues of education and language learning and teaching, named by the Spolsky as (Educational Linguistics). It includes arguments in favour and against Spolsky's proposed model(s) regarding educational linguistics and its relation to (General Linguistics, Linguistics and Applied Linguistics).

The study also accounts briefly for main issues accounted for by educational linguists. The researcher has to a great extent depended on [theoretical date] that is [original] and early writings regarding this field of study.

In short, this research-paper [monograph] will start with mentioning the origins of this field (Educational Linguistics) in relation to other fields (General Linguistics, Linguistics and Applied Linguistics). After that, early definitions of this field along with some proposed definitions by the researcher will be declared. The part before the final one will include the issues accounted for by educational linguists, but in between, the researcher will introduce both Spolsky's models for the place of educational linguistics and the researcher's [proposed/suggested] [alternative] models.

\section{Origin and definitions of educational linguistics}

Naturally, language is a means of human communication, they say. Technically, a 
language is a means of learning, teaching, pedagogical communication and gaining knowledge. Conversely, talking about language technically means in one way or another talking about the contents of language, that is, linguistics. The [word/term/] linguistics has many definitions but for our concern let us say, the [scientific] study of language which basically includes the study and description of issues including: Phonetics, Phonology, Morphology, Syntax and Semantics, etc. One more element which needs to be defined here is education; it is generally the formal and informal processes of learning, teaching and gaining/acquiring, approaching knowledge in all its fields and branches.

As a matter of fact, discussing a topic such educational linguistics means in one way or another brining education and linguistics together. Simply put, how does education interrelates with linguistics and vice versa? As far as I am concerned, the answer of this particular raised question is no way the answer of asking a question as what does educational linguistics stands for, (Gannon \& Czerniewska, 1980)?

Before introducing educational linguistics, one needs to introduce its origins and for that matter, applied linguistics must be introduced briefly here.

Applied Linguistics is a quickly growing field of study. Essentially, the use of this term in the journal of Language Learning: a Quarterly Journal of Applied Linguistics, in 1948, has marked the beginning of this field. After this term has appeared in that journal a number of the schools centres and associations have been established called after this name. From among them are: School of applied Linguistics, in Britain, Center of Applied Linguistics (CAL), The Association Internationale de Linguistique Appliquee (AILA), British Association of Applied Linguistics (BAAL), and American Association of Applied Linguistics (AAAL). These journals, schools, centres, associations and many others have greatly participated to the development of this field, (Spolsky \& Hult, 2008).

In spite of this, from another point of view, these various associations, centres mainly the journals which have been published officially to represent the ideas of each association or centre have indirectly affected negatively the study of this field. In other words, the many definitions of this field, the continuous arguments and more importantly the different and the far from each one another views and principles regarding Applied linguistics, have all made it an enemy-like field for linguistics, (ibid).

Principally, this field has started, they say, as a term referring to the language teaching, pedagogy and learning whether be it Arabic, English, French, German, Chinese, Russian, etc, or be it the teaching and learning as foreign language (FL) or second language (SL), etc, (Baker, 2001), and (Swarbrick, 1994) and (May, 2008).

However, arguments between linguists and proponents of applied linguistics have been arisen. These arguments include issues such as the claim that the former ones (linguists) are producers of theories while the latter ones (applied linguists) are consumers of these theories, (Spolsky, 2008), and (Corder, 1973: P 10) in (James, 1980).

Afterwards, new fields of language study have appeared which include sociolinguistics, psycholinguistics, educational linguistics, stylistics, discourse analysis, pragmatics, and more 
recently neurolinguistics, clinical linguistics and forensic linguistics. Before the emergence of these fields, linguistics was including fields such as phonetics, phonology, morphology, syntax, historical linguistics (etymology and anthropology) and semantics. For that matter, the new established fields have been mentioned by some linguists and scholars as [hyphenated] fields of linguistics. Consequently, this was against the ideas of some other scholars who have argued that what have been considered as [hyphenated] fields of linguistics are actually not. Differently put, they are the concern and issues of applied linguistics. This view has resulted to a new definition of applied linguistics, a field which accounts for the above mentioned [hyphenated] field of linguistics, (Hult in Spolsky and Hult, 2008).

Despite this, the issue of what is applied linguistics remains questionable and unanswerable to the extent that an applied linguist would be mentioned as 'site-less and sightless', (Davies, 2004: p.3). More importantly, some scholars would argue from another point of view that applied linguistics to include fields and issues such as educational linguistics is a misleading point. From among these scholars who unsatisfactorily believe that applied linguistics is to a great extent general and misleading term to be a place for language pedagogy is Spolsky. For that matter, educational linguistics, [a new field of study] has been established by Spolsky, in nearly 1978.

In the 1978s, Spolsky an Emeritus professor of linguistics mainly educational linguistics has published an article (monograph) arguing that language teaching and learning, and education must be included in a field which he called (Educational Linguistics). This name has come as an opposing name for [applied linguistics] mainly the applied linguistics which was referred to language teaching and pedagogy.

In his book, Spolsky (1978: pp. 1-2) indicated that the term applied linguistics is 'unfortunate' to be referred to language studies and education 'for two reasons', (ibid). He continues, the first reason is that 'the field of applied linguistics is wider than the application of linguistics and education', (ibid). Spolsky turns the reason of this for that applied linguistics does not only include 'language teaching, but also translation, lexicography, language planning, and many other areas of practical relevance', (ibid). The second reason is 'the implication that linguistics must be applied to something', (ibid: p. 2).

Cooper, Shohamy and Walters (2001: pp. 2-3) introduce educational linguistics as 'a term borrowed from educational psychology and educational sociology'. They go on, 'Spolsky describes educational linguistics as a branch of applied linguistics, further specifying the following subfields: language education policy and planning, first and second language acquisition and teaching, reading literacy, and composition; mother tongue and bilingual education, minority and immigrant education, and language testing', (ibid).

One more definition of educational linguistics is brought by (Richards, 2002: p. 174) who defines it as 'a term sometimes used to refer to a branch of APPLIED LINGUISTICS which deals with the relationship between language and education'.

Additionally, (Crystal, 1997: p. 163) defines technically educational linguistics as: 
A term sometimes used for the application of LINGUISTIC theories, methods and descriptive findings to the study of the teaching/learning of a native language, in both spoken and written forms, in schools or other educational settings; more broadly to all teaching contexts; also called pedagogical linguistics and sometimes language pedagogy. Specific topics of interest include the study of reading and writing, ACCENT and DIALECT, language VARAIETY across the curriculum, and the teaching of linguistics, GRAMMAR, etc. in schools.

One more definition is introduced by Hult in (Spolsky's and Hult's, 2008: p. 10). He states, 'educational linguistics is an area of study that integrates the research tools of linguistics and other related disciplines of the social sciences in order to investigate holistically the broad range of issues related to language and education'.

Contrastively, (Bussmann, 1996: p. 77) introduces language pedagogy as a field/ branch of applied linguistics which he (ibid: pp. 419, 647) indirectly defines as the field which includes the discussion and practice of everything related to language teaching/learning whether be it first, second or foreign language.

A final element to be mentioned here along with the above mentioned definitions is (Gannon's and Czerniewska's, 1980: pp. 1-16) who in their book show from one side the interrelation of education and linguistics, that is what linguists should provide educationalists with and vice versa. Yet, from another point of view, they introduce linguistic fields such as semantics, grammar, phonology and discourse with a detailed description of how a teacher should analyze each one. In one way or another, their book, indicates something which is the issue of this research-paper. Amazingly, they have never mentioned in their book what is being known as educational linguistics though the issues they accounted for in this book are the heart of this field of study that is educational linguistics.

In effect, the truth that language and educational matters forms together what is called educational linguistics cannot be denied. In spite of this, it is important to know why educational linguists lead by Spolsky who is considered as the proponent of this field have argued that educational linguistics is something different from applied linguistics. In other words, why does Spolsky exempted the term Applied Linguistics from what he has called in his book (fuller proposed model) for Educational Linguistics? More importantly, why does Hult claim that only the history of educational linguistics is 'inextricably linked to applied linguistics' but not the field itself is [intricately] related to applied linguistics? Lastly but not the least, does educational linguistics a field of study by itself just as Spolsky have claimed or he has only originated/ organized it, but its roots were really there in applied linguistics? These questions are the main issue of this coming part in this research-paper.

To begin answering the above raised question, it is worthy to show Spolsky's model as they have appeared in his book, (Spolsky, 1978: pp. 4-5). After Spolsky's models are presented, [the researcher suggested models] are shown and then are supported by some arguments and opinions. 
7
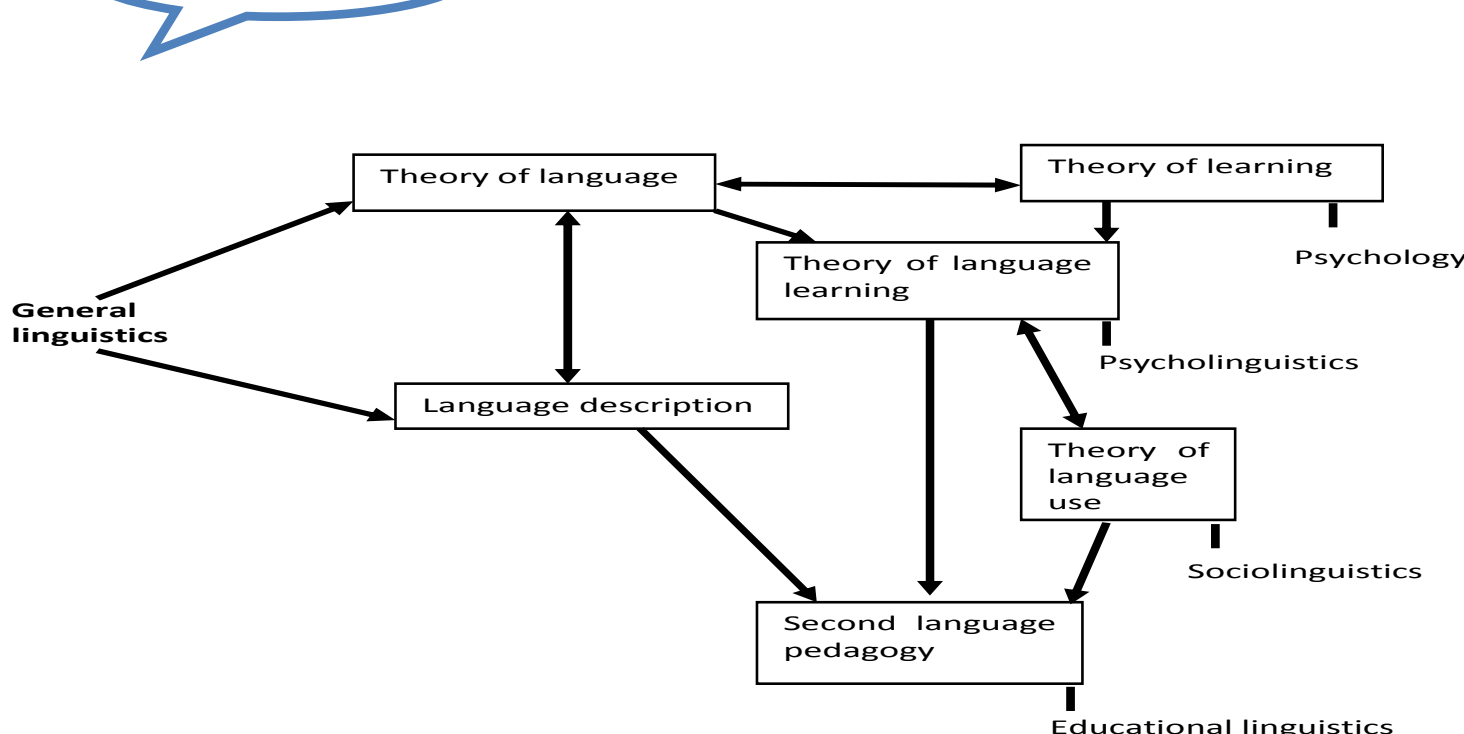

Figure 1: Spolsky's early model of educational linguistics

\section{Spolsky's proposed
fuller model}
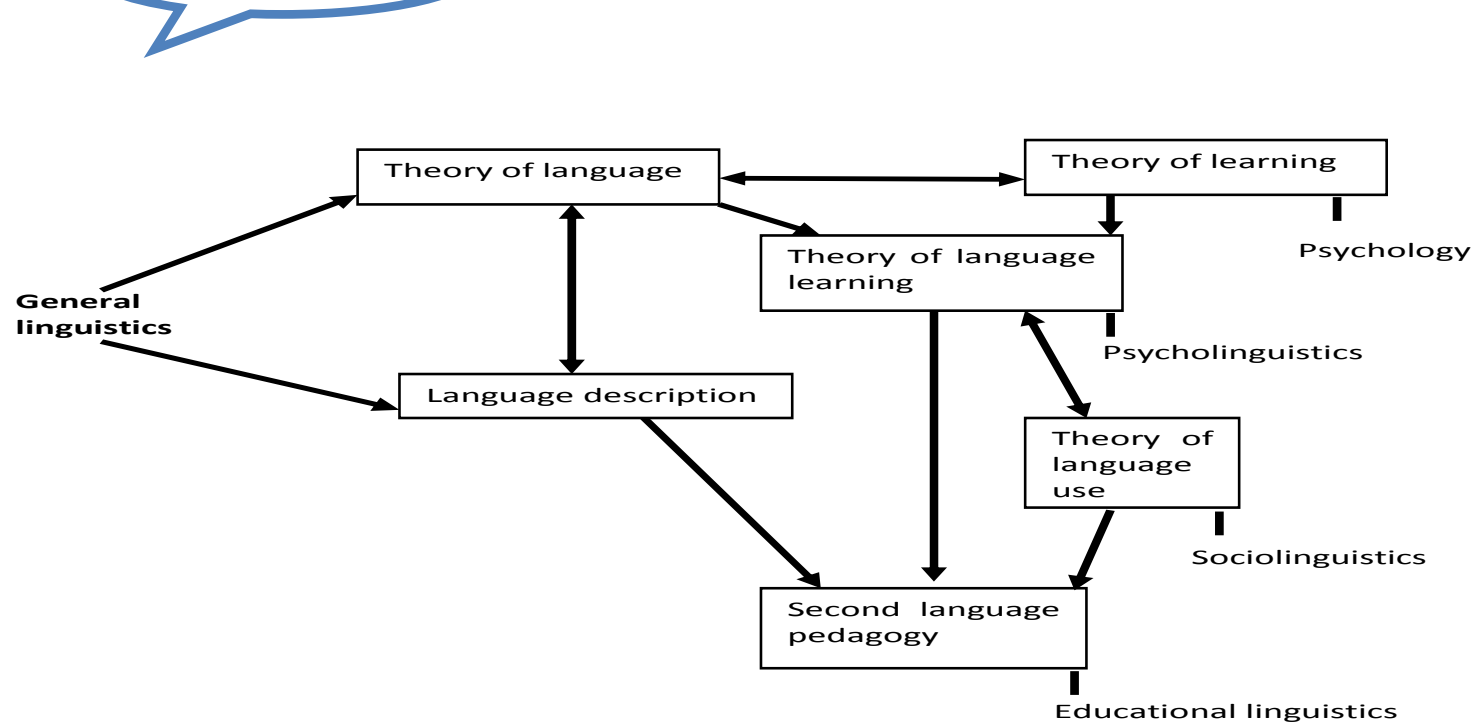

Figure 2: Spolsky’s proposed fuller model of educational linguistics 


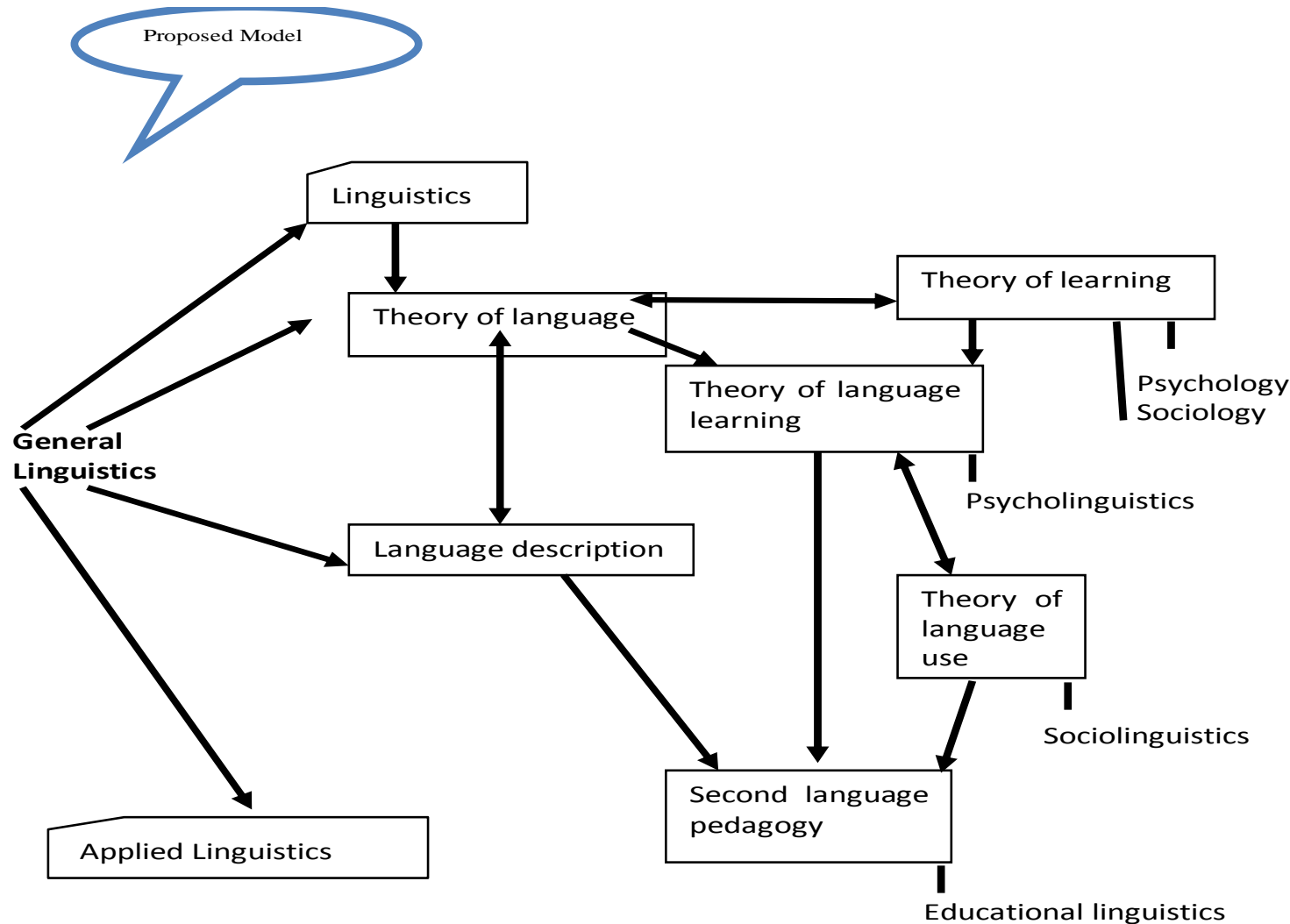

Figure 3: Alduais’s proposed model of educational linguistics 


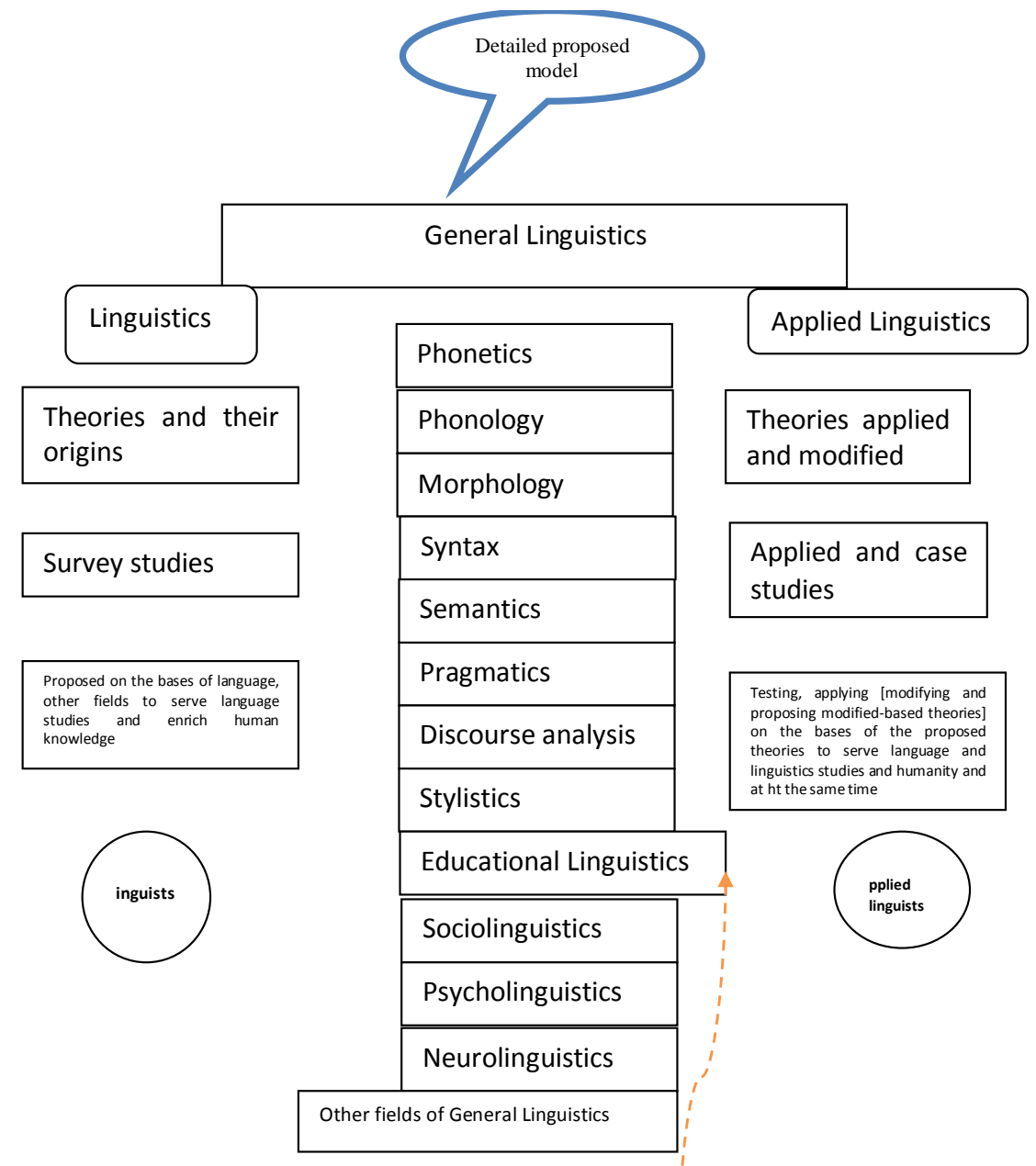

Language and Education

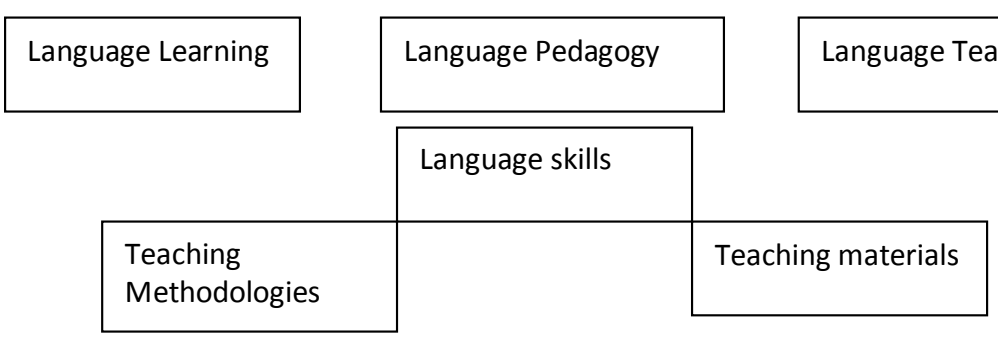

Figure 4: Alduais’s proposed fuller model of educational linguistics

As a matter of fact, similar to the early opinions/ definitions of applied linguistics is Spolsky's view which appears in his early model, (mentioned above, page: 7). In other words, it is clear that from that diagram that applied linguistics was referring to language teaching.

Later on and as it appears in Spolsky's revised model, (mentioned above, page: 7), applied linguistics has extended to include not only language teaching but also learning theory and pedagogy. More importantly, in this model, we have language theory separated from language description; unlike the case of the first model wherein they are modeled as one 
component and yet applied linguistics is a derived part from them both. Say it another way, in this case, applied linguistics is derived mainly from language description and one more theory is required which is learning theory, from this theory we have pedagogy wherein both language learning and teaching are in between.

Surprisingly, in his claimed proposed fuller model, Spolsky is no more mentioning or including the term/component applied linguistics, (shown above, page: 8). That is to say, more theories have shown up in this model, but applied linguistics have amazingly [disappeared]. In one way or another, what has been proposed by Spolsky here is not to a great extent true for a number of reasons which I will discuss.

Firstly, if we assume that really applied linguistics is a too general term to indicate language study and education, this is no way true. Yet, we should not deny the fact that issues such as language pedagogy, language teaching, etc. have started as elements and issues accounted by applied linguistics. More importantly, if it is true and I believe in this way it is, that applied linguistics is a wide field of study and it includes all (hyphenated) fields of linguistics; it should not be ignored that educational linguistics [must] be in one way or another a branch/part or whatever of applied linguistics, (Trappes-Lomax, 2002) and (Lambert, 2000). Actually, this should happen because of the fact that both education and language learning are as old as human beings whether are it performed in the traditional way or technologically. For that matter, if the application of these theories and the new updated and inserted modifications of language: teaching, learning and pedagogy theories are not included to form educational linguistics, it means that Spolsky has really done nothing except bringing the name for these issues.

To refer to applied linguistics, it is important to note that either we should assume that general linguistics has two basic components which are: linguistics, theoretical linguistics or pure linguistics and applied linguistics, (Browne, 2001). Or, we could assume that in language study(s) in general, we have two processes: theory and description, and practice; the former which will include all the components mentioned in the proposed diagram by the researcher (pages: 9 and 10) will be the task of linguists who would produce/make theories and describe language at the same time. The latter (practice) is the task of applied linguists who would practice/apply the proposed theories by linguists, but more importantly modify and produce other theories on the bases of the early proposed theories by linguists. For one reason or another, the tasks of both linguists and applied linguists are intricately interrelated.

One more view might be that pure linguistics is different from applied linguistics and in this way the former contains what the latter does not contain. In other words, fields known as Phonetics, Phonology, Morphology, Syntax and Semantics are the concern of linguistics/ theoretical linguistics or pure linguistics. On the other hand, what has been called by some linguists as hyphenated fields of linguistics will be no more fields of linguistics, instead, they are the issues of applied linguistics. These fields would include generally: educational linguistics, sociolinguistics and cognitive linguistics. In details and specifically, each general field will include sub-fields.

Educational linguistics, for instance, will include language teaching, language learning, 
language pedagogy, language teaching policy and planning, preparation of teaching and learning materials prospectively. Sociolinguistics would include pragmatics, discourse analysis, text analysis and stylistics. And finally cognitive linguistics would include sub-fields as: psycholinguistics, neurolinguistics, clinical linguistics and [biological] linguistics prospectively. Other issues would include contrastive analysis, error analysis, language acquisition and comparative linguistics which is actually part of the historical linguistics and which I believe is more related to pure linguistics rather than applied linguistics as it is sometimes wholly based on [untested] assumptions.

On account of this, one can infer that educational linguistics [must] be included as a branch of applied linguistics. That is, if it is only mentioned or considered as a new branch of linguistics study which relates both education and language study, then, there is no clear difference between the processes of education, language learning and language education in the past and in nowadays except for the name. Actually, it seems that we need to include educational linguistics as part of applied linguistics in order to make our teaching and learning processes at least scientific-like.

In order to produce more effective methods of teaching, more experienced teachers, more effective teaching and learning materials and so on, we need to make our education processes as much practical as we can. The gap between theory and practice in our schools, universities and all places where languages are taught and learned, must be filled in with something practical; these practical matters are no way, but to be taken from applied linguistics which functions as supporter for educational linguists who in turn will enhance and provide teachers of languages with what and how they should teach. Needless to say, educational linguists and applied linguists as well have to make an extensive use and consultancy of all the things produced by linguists, which function to them as feedback by which they can depend on/modify, etc, ([with reference to Guerrero, 2005) and (Granger, 1998).

It is important to note that we need applied linguistics in educational linguistics in order to test, evaluate and assess what linguists have given us as linguists in some cases tend to produce educational text-books. We need to know, to what extent these produced/made text-books would suit the level, the needs, and etc. of our learners, so that we can modify, suggest, replace or add some materials, etc. differently put, instead of having educationalists and linguists, we have here educational linguists who by their balanced knowledge of education and language can find out and determine what suits and what does not suit the needs of learners of a particular language in a particular level. More importantly, this does not only happen in the case of learning or teaching a second or foreign language but in the native tongue language as well, (Kumaravadivelu, 2006) and (Lier, 2004).

\section{Issues, educational linguistics accounts for}

Have introduced educational linguistics namely its origins and definition(s), it is worthy now to account for the issues that educational linguistics accounts for, (the scope of educational linguistics). 
With reference to some of Spolsky's materials/sources regarding this field, one can notice at least from the contents of his books/articles, monograph(s) that this field will include topics/issues such as how a language should learned/taught? What are the methodologies that should/must/would or can be followed to properly and effectively teach or learn that or this particular language? Why this particular method but not that one is more effective in teaching or learning a language? Additionally, why one particular method would suit in one situation but not in other situation(s)?

Hult in (Spolsky and Hult, 2008) declares that the scope of educational linguistics has started with constant relation to issues accounted for by applied linguists/linguistics, but later on has flourished and considerably developed. As far as I am concerned, this indicates at least two things: one is that educational linguistics has started as branch of applied linguistics and for that matter it should remain as a branch of applied linguistics. Secondly, since educational linguistics contains or accounts for issues which have been accounted for by applied linguistics so educational linguists [should] accept the fact that they do need to make use of both linguists' and applied linguists' productions.

To refer to our issue which is issues accounted for by educational linguistics/linguists, typically, it accounts for issues such as language teaching methodology, learning language methodology, teaching/learning a language as either foreign or second language (SLTL \& FLTL), teaching/learning a language for either academic or specific/special purposes (LLTAP \& LLTSP) and lastly but not the least preparation of teaching and learning languages' materials (syllabus/curriculum design). Other issues which are accounted for by educational linguists would include [matters] such as bilingualism, multilingualism, and so on.

Basically, educational linguists will provide teachers with all kind of materials, for all levels and for all needs and purposes. On one hand, they need to prepare materials for the skills of the taught/learned language. On the other hand, they need also to prepare a number of theories/methods and approaches for the teachers of this or that language so that they can choose what suits the circumstances, situations he or she is teaching in, (Ferguson, 2006) and (Heller, 2001).

When it comes for speaking and listening skills, teachers need to know how to teach, from where to start, what to start with, what kind(s) of materials are the most active and effective one for the level of the learners he or she is going to teach/deal with and more importantly how should he or she deal with his/her learners/students: is it different when teaching a language as second, foreign and native, etc.? As for our learners/students, they need materials; materials that will really help them to get the basics of beginners, move to another level if intermediate level and improve their level if they are in an upper-intermediate level, (Butler, 2002) and (Bot, 2000).

Similarly, in the case of the reading and writing, both teachers and students/learners need teaching and learning materials. Moreover, they also need; teachers, teaching methodologies so that they can manage how to teach their pupils/students effectively in a way that makes them produce productively what they have learnt/received theoretically, (Butler, 2002). 
One more area where in educational linguists deal with is teaching a language for either specific/special or academic purposes. In the former case, a particular language like English for example is being extensively taught for many and different purposes. In other word, English is taught for business purposes for those who are travelling around the world and English is used as means of communication in nearly all over the world. In this case, educational linguists need to prepare the suitable teaching and learning materials that will in one way or another enable these/those kind of learners to communicate in English so that they can perform well in their jobs and business life, (Hyland, 2006) and (Nation, 2009) and (O’Connell, 2007).

Other examples for teaching a language for specific purposes will include tourism, science (physics, chemistry, biology, microbiology, architecture, geometry, finance, medicine, and etc.), and for social sciences as required courses/subjects. Similar to the above mentioned case, in all these cases, educational linguists [must] pay into consideration that each of which have their own goals and purposes for learning this or that language which indicate one group will need some lessons/topic which another group does not need and so on, (Nation, 2009).

Once again, educational linguists would face another kind of learning and teaching a language which is teaching a language for academic purposes (TLLAP), (EAP). In this case, it seems that our learners are expected to have a higher level of English which is at least they can read and write well. In other words, especially for those who are doing their higher studies in English or any other language, they need to understand what is said and what is written so that they can write and catch as much information as they can. Put another way, the case here is far than communication that is students need to understand nearly everything said during the lecture and more importantly they can read and consult all kind of academic books, journals, theses and dissertations in their field of study and manage to write about it lucidly and clearly, (Hyland, 2006).

Additionally, when teaching or learning a language, it is either taught/learnt as a foreign or second language. In principle, teaching/learning a language as a foreign is entirely and to some extent different from teaching/ learning it as a second language. To make it clear, [and educational linguists who should make it clear], in the former it is to some extent similar to teaching/ learning a language for specific purposes and the latter is partially similar to the teaching/ learning of a language for academic purposes [prospectively], (Johnson, 2009) and (Kachru, 2006) and (Reagan, 2002) and (Bot, 2000).

On account of this, educational linguists may account for issues such as (Bilingualism and Multilingualism). In details, a country where in two language are used as means of communication is to be regarded as a bilingual country/people. An example for this case is India where in they have a number of official languages related to their language, but the language which relate them is English. Moreover, European countries mainly European Community/Union (EU), it has been proposed to launch a language programme wherein at least one of the European's language is taught in a member's country along with the native language of this or that particular country. Other countries specifically in Africa they speak more than a language, usually their native tongue language and French language, (Baker, 
2001) and (Cummins, 2007) and (Edwards, 1994).

In all cases, therefore, educational linguists [have] to work on nearly all the things related to the processes of launching or doing a programme like this or that one. Yet, they may need some help from decision-makers, but after that it is their job to prepare materials for both teaching and learning and to start making reports about the advantages and disadvantages of having such a phenomenon, (Harris, 1990) and (Horowitz, 2005).

In my opinion, the most important thing which educational linguists have to do and which makes them different from all- educationalists, linguists and [teachers/educators] but not necessarily applied linguists is the searches and applied studies which they have to conduct attempting to identify what is going on. In other words, their researches should in one way or another investigate the effect of the materials which they have prepared/recommended for both teachers and learners. The studies should also include evaluation and assessments processes in order to see to what extent the determined goals of our learners, society needs, or even goals proposed by decision-makers for the development of the country through developing the human resources.

In effect, educational linguistics accounts for [all] matters related to language teaching and learning and for that matter educational linguists must have enough knowledge of not only linguists but also educational issues, at least basics of psychology and sociology as well and of course referring to other fields/branches in applied linguistics.

\section{Conclusion}

This paper is a monograph that aimed at introducing the field of educational linguistics. However, this field has been first accounted for from the point of view of the [proponent] of this field, Spolsky and his followers. It was argued in this paper against the view that educational linguistics is only 'inextricably' related to the history of applied linguistics. The researcher, however, has argued through his [proposed] models and arguments that educational linguistics is intricately related to applied linguistics but not only to its history. Hence, other arguments along with a number of the definitions of this field have been mentioned.

Having introduced the origin and a number of the definitions of educational linguistics, the researcher has accounted for the issues which educational linguistics accounts for. In general, these issues included all matters of language: learning, teaching, pedagogy, teaching methodologies, preparation of both teaching and learning materials and issuing social and psychological factors as well with the possibility of integrating with special education issues.

For all intents and purposes, this study accounts for this field and it has been introduced from different points of view. Thus, in one way or another it helps researches and those who may be want to join this field as their [major] field of study or even minor to know where does it come from, what does it refer to, what does it account for and what is agreeable and disagreeable bout it? 


\section{Acknowledgement}

The author would like to acknowledge the help of Prince Salman Library, the main library of King Saud University (KSU) Libraries for making the needed books in the field at reach.

\section{References}

Baker, C. (2001). Foundations of Bilingual Education and Bilingualism (3 ed.). Clevedon • Buffalo • Toronto • Sydney: Multilingual Matters LTD [Electronic version].

Bartels, N. (Ed.). (2005). Applied Linguistics and Language Teacher Education. Springer Science + Business Media, Inc [Electronic version].

Bot, K. d. (2000). Second Language Acquisition An advanced resource book. London and New York: Routledge: Taylor and Francis Group [Electronic version].

Browne, A. (2001). Developing Language and Literacy 3-8. 6 Bonhill Street, London EC2A 4PU: Paul Chapman Publishing, A SAGE Publications Company [Electronic version].

Bussmann, H. (1996). Dictionary of Language and Linguistics. (K. Kazzazi, Ed., \& G. Trauth, Trans.) London and New York: Routledge [Electronic version].

Butler, K. G. (Ed.). (2002). Speaking, Reading, and Writing in Children With Language Learning Disabilities: New Paradigms in Research and Practice. Mahwah, New Jersey London: Lawrence Erlbaum Associates, Publishers [Electronic version].

Cooper, R. L. (Ed.). (2001). New Perspectives and Issues in Educational Language Policy: A festschrift for Bernard Dov Spolsky. Amsterdam/Philadelphia: John Benjamins Publishing Company [Electronic version].

Crystal, D. (1997). A Dictionary of Linguistics and Phonetics (4th ed.). Blackwell: Blackwell Publishing [Electronic version].

Cummins, J. (Ed.). (2007). International Handbook of English Language Teaching (Parti). Springer Sciences-Business Media, LLC. [Electronic version]. http://dx.doi.org/10.1007/978-0-387-46301-8

Davies, A. (Ed.). (2004). Blackwell Handbooks in Linguistics: The Handbook of Applied Linguistics. 350 Main Street, Malden, MA 02148-5020, USA, 108 Cowley Road, Oxford OX4 1JF, UK, 550 Swanston Street, Carlton, Victoria 3053, Australia: Blackwell Publishing Ltd [Electronic version]. http://dx.doi.org/10.1002/9780470757000

Edwards, J. (1994). Multilingualism. London and New York: Routledge: Taylor and Francis Group [Electronic version]. http://dx.doi.org/10.4324/9780203430927

Ferguson, G. (2006). Language Planning and Education: Edinburgh Textbooks in Applied Linguistics. 22 George Square, Edinburgh: Edinburgh University Press Ltd [Electronic version]. 
Gannon, P. (1980). Using Linguistics: An Educational Focus. London: Edward Arnold (Publishers) Ltd [Electronic version].

Granger, S. (Ed.). (1998). Learner English on Computer. London and New York: Addison Wesley Longman Limited [Electronic version].

Guerrero, M. C. (2005). Inner Speech - L2 Thinking Words in a Second Language. Springer Science+Business Media, Inc. [Electronic version].

Harris, J. (1990). Early Language Development: Implications for clinical and educational practice. London and New York: Routledge: Taylor and francis Group [Electronic version].

Heller, M. (Ed.). (2001). Voices of Authority: Education and Linguistic Difference (Vol. 1). Westport, Connecticut London: Ablex Publishing [Electronic version].

Horowitz, M. C. (Ed.). (2005). New Dictionary of the History of Ideas. Charles Scribner's Sons [Electronic version].

Hyland, K. (2006). English for Academic Purposes: An Advanced Resource Book. London and New York: Routledge: Taylor and Francis Group [Electronic version].

James, C. (1980). Contrastive Analysis: Applied Linguistics and Language Study . (C. N. Candlin, Ed.) Essex: Longman Group Limited .

Johnson, K. E. (2009). Second Language Teacher Education: A Sociocultural Perspective. London and New York: Routledge: Taylor and Francis Group [Electronic version].

Jouranl of Language, I. a. (2002). Jouranl of Language, Identity, and Education 1 (4). London: Lawrence Erlbaum Associates, Inc. [Electronic version].

Kachru, B. B. (Ed.). (2006). Blackwell Handbooks in Linguistics: The Handbook of World Englishes. 350 Main Street, Malden, MA 02148-5020, USA, 9600 Garsington Road, Oxford OX4 2DQ, UK, 550 Swanston Street, Carlton, Victoria 3053, Australia: Blackwell Publishing Ltd [Electronic version].

Kumaravadivelu, B. (2006). Understanding Language Teaching: From Method to Postmethod. Mahwah, New Jersey London: Lawrence Erlbaum Associates, Publishers [Electronic version].

Lambert, R. D. (Ed.). (2000). Language Policy and Pedagogy: Essays in Honor of A. Ronald Walton. Philadelphia /Amsterdam: John Benjamins Publishing Company [Electronic version].

Lier, L. v. (2004). The Ecology and Semiotics of Language Learning: A Sociocultural Perspective. New York, Boston, Dordrcht, London, Moscow: Springer Science + Business Media, Inc. [Electronic version]. http://dx.doi.org/10.1007/1-4020-7912-5

May, S. (Ed.). (2008). Encyclopedia of Language and Education: Language Policy and Political Issues in Education (Vol. 1). Springer Science+Business Media, LLC. 
[Electronic version].

Nation, I. S. (2009). Teaching ESL/EFL Listening and Speaking. New York: Routledge [Electronic version].

Nero, S. J. (Ed.). (2006). Dialects, Englishes, Creoles, and Education. Mahwah, New Jersey London: Lawrence Erlbaum Associates, Publishers [Electronic version].

O’Connell, M. E. (Ed.). (2007). International Education and Foreign Languages: Key to Securing America's Future. Washington, D. C., The National Academies Press: [Electronic version].

Reagan, T. G. (2002). The Foreign Language Educator in Society: Toward a Critical Pedagogy. Mahwah, New Jersey London: Lawrence Erlbaum Associates, Publishers [Electronic version].

Richards, J. C. (2002). Longman Dictionary of Language Teaching and Applied Linguistics. London, New York, Toronto, Syndey, Tokyo, Singapore, Hong Kong, Cape Town, New Delhi, Madrid, Paris, Amsterdam, Munich, Milan, Stockholm: Pearson Education Limited [Electronic version].

Spolsky, B. (1978). Educational Linguistics: An Introduction. Rowley, Massachusetts: Newbury House Publishers, INC.

Spolsky, B. (Ed.). (2008). The Handbook of Educational Linguistics. 350 Main Street, Malden, MA 02148-5020, USA, 9600 Garsington Road, Oxford OX4 2DQ, UK, 550 Swanston Street, Carlton, Victoria 3053, Australia: Blackwell Publishing Ltd [Electronic version]. http://dx.doi.org/10.1002/9780470694138

Swarbrick, A. (Ed.). (1994). Teaching modern languages. London and New York in association with The Open University: Routledge: Taylor and Francis Group [Electronic version].

Trappes-Lomax, H. (Ed.). (2002). Language in Language Teacher Education. Amsterdam/Philadelphia: John Benjamins Publishing Company [Electronic version].

\section{Copyright Disclaimer}

Copyright reserved by the author(s).

This article is an open-access article distributed under the terms and conditions of the Creative Commons Attribution license (http://creativecommons.org/licenses/by/3.0/). 